\title{
STATUS BERKELANJUTAN KOTA TANGERANG SELATAN-BANTEN DENGAN MENGGUNAKAN KEY PERFORMANCE INDICATORS (Sustainable Status of South Tangerang City-Banten Using Key Performance Indicators)
}

\author{
Heri Apriyanto ${ }^{1,2^{*}}$, Eriyatno ${ }^{1}$, Ernan Rustiadi ${ }^{1}$ dan Ikhwanuddin Mawardi ${ }^{2}$ \\ ${ }^{1}$ Sekolah Pascasarjana, Insitut Pertanian Bogor, Pusat Studi Pengelolaan Sumber Daya Alam dan \\ Lingkungan, Kampus IPB Baranangsiang, Bogor, 16144. \\ ${ }^{2}$ Badan Pengkajian dan Penerapan Teknologi, Kawasan Puspiptek Serpong, \\ Tangerang Selatan, 15413. \\ *Penulis korespondensi. No Tel: +6281282985911.; Email: heriap@yahoo.com.
}

Diterima: 25 Maret 2015

Disetujui: 7 Mei 2015

\begin{abstract}
Abstrak
Pembangunan kota yang tidak terkendali akan mengakibatkan tekanan terhadap lingkungan dan beban masyarakat meningkat, sebaliknya degradasi lingkungan akan mengakibatkan pembatasan pengembangan ekonomi dan penurunan kualitas hidup. Guna mencegah terjadinya dampak-dampak negatif, maka diperlukan prinsip-prinsip pembangunan kota yang berkelanjutan. Evaluasi terhadap pelaksanan pembangunan kota yang berkelanjutan perlu dilakukan untuk mengetahui apakah pembangunan suatu kota sudah atau belum/tidak berkelanjutan. Penelitian ini bertujuan untuk menyusun Key Performance Indicators (KPI) guna menilai status pembangunan kota berkelanjutan. Perumusan KPI ini dilakukan dengan pendekatan Analytic Hierarchy Process (AHP). KPI yang dihasilkan terdiri dari 21 indikator dan 9 elemen dari 3 pilar pembangunan berkelanjutan (ekonomi, sosial, dan lingkungan). Implementasi KPI dilakukan untuk pengukuran status keberlanjutan Kota Tangerang Selatan. Hasil pengukuran menunjukkan bahwa kota ini termasuk dalam tahap awal pembangunan berkelanjutan. Secara umum perkembangan ekonomi dan sosial relatif cukup baik, namun tidak demikian dengan kondisi lingkungannya.
\end{abstract}

Kata kunci: key performance indicators, kota berkelanjutan, pembangunan kota, status, Tangerang Selatan

\begin{abstract}
Uncontrolled urban development will result in pressure on the environment and the burden of the people. On the contrary, environmental degradation will lead to restricted economic development and decreased quality of life. In order to prevent negative impacts, it is necessary to implement the principles of sustainable city development. Evaluation of the implementation of sustainable city development is needed to determine whether the development of a city is sustainable or not. This study aimed to develop Key Performance Indicators (KPI) to assess the status of sustainable city development. The formulation of KPI is done with Analytic Hierarchy Process (AHP). KPI generated consists of 21 indicators and 9 elements of the 3 pillars of sustainable development (economic, social, and environmental). Implementation of KPI conducted to measure the sustainable status of South Tangerang City. The results show that the city is in the early stages of sustainable development. In general, economic and social development is relatively good, but not so good with the environmental conditions.
\end{abstract}

Keywords: city development, key performance indicators, sustainable city, status, South Tangerang

\section{PENDAHULUAN}

Pertumbuhan penduduk perkotaan semakin pesat seiring dengan perkembangan perekonomian, pemukiman, pendidikan, dan budaya. Daya tarik kota yang sangat besar bagi penduduk desa mendorong angka laju urbanisasi semakin cepat. Peningkatan jumlah penduduk daerah perkotaan menimbulkan tekanan cukup besar terhadap sumberdaya dan lingkungan perkotaan (Setyowati, 2008). Perkembangan dan keberlangsungan sebuah kota selalu dikaitkan dengan peningkatan konsumsi terhadap material dan sumber daya alam yang ada. Limbah yang dihasilkan dalam proses ini berdampak buruk terhadap lingkungan alam sehingga pada akhirnya akan mengarah pada pembangunan kota yang tidak berkelanjutan (Dou dkk., 2013). Beberapa tahun terakhir ini, isu lingkungan yang terkait dengan perkembangan ekonomi yang pesat semakin menjadi perhatian penting oleh pemerintah pusat dan daerah (Guan dkk., 2011). Terjadi umpan balik di mana degradasi lingkungan akan mempengaruhi pengembangan ekonomi dan sosial dengan adanya batas nyata untuk pertumbuhan dan memburuknya kualitas hidup (Diaz, 2011). Permasalahan yang sering dijumpai di kawasan perkotaan antara lain adanya kawasan kumuh, pencemaran, kurangnya sanitasi, konflik masyarakat, kemacetan, dan sebagainya. 
Salah satu upaya untuk mengatasi ataupun mencegah timbulnya permasalahan secara lebih meluas adalah dengan pembangunan kota baru yang lebih terencana. Konsepsi pembangunan kota baru ini telah diterapkan oleh Pemerintah Indonesia sebagai salah satu alternatif dalam mengatasi permasalahan perkotaan, khususnya di kota besar dan metropolitan. Pembangunan kota baru ini merupakan salah satu implementasi dari kebijakan pemerintah melalui Instruksi Presiden No. 13 Tahun 1976 tentang Pengembangan Wilayah Jabotabek (Jakarta, Bogor, Tangerang, dan Bekasi).

Pembangunan Kota Bumi Serpong Damai/BSD (di Kecamatan Serpong), Bintaro Jaya (di Kecamatan Pondok Aren), dan Alam Sutera (di Kecamatan Serpong Utara), serta Pamulang-Ciputat merupakan beberapa kota baru sebagai alternatif pusat-pusat pertumbuhan untuk bagian sebelah barat Jakarta. Pusat-pusat pertumbuhan tersebut pada akhirnya menjadi pilar utama terbentuknya Kota Baru Tangerang Selatan sebagai Daerah Otonom Baru (DOB) pada tahun 2008. Setelah menjadi daerah otonom, maka kota ini bergerak cepat menggerakkan roda perekonomiannya. Berdasarkan data PDRB tahun 2012-2013, kondisi perekonomian kota ini relatif tinggi, di mana sektor tersier lebih dominan, yaitu pengangkutan dan komunikasi, perdagangan, hotel dan restoran, jasajasa dan bank, serta persewaan dan jasa perusahaan, telah memberikan kontribusinya lebih dari $70 \%$ dari struktur ekonomi yang ada. Sektor sekunder (industri pengolahan, listrik, gas dan air bersih, dan konstruksi) memberikan kontribusi sekitar 27\%, dan sektor primer (pertanian; pertambangan dan penggalian) hanya memberikan kontribusi kurang dari 1\% (Anonim, 2013).

Pembangunan Kota Tangerang Selatan pada saat ini masih cenderung mengedepankan orientasi keekonomian saja. Tentunya hal ini nantinya dapat menimbulkan kerentanan bahaya aspek lingkungan (daya dukung yang tidak mampu lagi untuk menunjang perkembangan kota) dan sosial (beban masyarakat meningkat). Dampak negatif tersebut harus dicegah atau diminimalisir dengan upaya pengendalian pembangunan kawasan perkotaan dengan menerapkan prinsip pembangunan berkelanjutan. Untuk itu agar pembangunan kota ini dapat secara berkelanjutan, maka diperlukan suatu kebijakan yang mengharmonisasikan tatanan ekonomi, tatanan ekologis, dan tatanan sosial. Sistim ekonomi hanyalah merupakan salah satu dari totalitas tatanan yang ada, dengan demikian kepentingan ekonomi tidak lagi mendominasi, tetapi justru tergantung secara ekologis dan sosial. Hal tersebut dimaksudkan untuk menjamin adanya keberlanjutan dalam pemanfaatan sumberdaya alam yang tersedia, tanpa mengurangi peluang generasi yang akan datang untuk menikmati kondisi yang lebih baik.

Perencanaan pembangunan berkelanjutan pada sistem perkotaan menitikberatkan pada keseimbangan aspek ekonomi, sosial, dan lingkungan (Chen dkk., 2006). Hal itu karena kota merupakan suatu ekosistem yang kompleks, di mana dipengaruhi oleh faktor-faktor sosial, ekonomi, lingkungan, dan budaya. Upaya untuk mencapai pembangunan perkotaan yang berkelanjutan ini merupakan suatu tantangan penting. Perkembangan indikator evaluasi dan metode untuk menilai status pembangunan berkelanjutan perkotaan akan diperlukan untuk mendukung perencanaan ekologi perkotaan, konstruksi, dan manajemen (Li dkk., 2009). Pelaksanaan evaluasi memerlukan suatu instrumen untuk penilaian status berkelanjutan. Instrumen ini terdiri dari berbagai indikator (ekonomi, sosial, dan lingkungan) sebagai tolok ukur untuk penilaiannya. Indikator-indikator tersebut selanjutnya diwujudkan sebagai Key Performance Indicators (KPI) untuk pembangunan kota baru berkelanjutan. KPI ini dapat diartikan sebagai ukuran yang akan memberikan informasi sejauh mana tingkat suatu keberhasilan dalam mewujudkan pembangunan kota yang berkelanjutan.

Berdasarkan review terhadap beberapa indeks/indikator berkelanjutan yang diterapkan untuk menilai keberlanjutan kota, disimpulkan bahwa perlu untuk menyusun City Sustainability Index (CSI) baru. CSI yang baru ini diharapkan mampu digunakan untuk penilaian dan perbandingan kinerja keberlanjutan kota dan pemahaman dampak global kota (kontribusi ekonomi) terhadap lingkungan dan kehidupan manusia (Mori dan Christodoulou, 2012). Saat ini belum terdapat indeks atau indikator yang komprehensif dan terintegrasi untuk penilaian status kota berkelanjutan.

Penelitian ini bertujuan menyusun KPI untuk menentukan status pembangunan kota baru berkelanjutan. KPI ini digunakan untuk menilai status pembangunan kota baru berkelanjutan di Indonesia yang sesuai dengan kondisi wilayahnya. Implementasi pengukuran status keberlanjutan dengan menggunakan instrumen ini dilakukan terhadap Kota Tangerang Selatan, Banten.

\section{METODE PENELITIAN}

Kerangka kerja penyusunan KPI dalam penelitian ini meliputi pemilihan indikator, tahapan pembobotan, dan penentuan status pembangunan berkelanjutan. Kerangka kerja tersebut disajikan pada Gambar 1. 


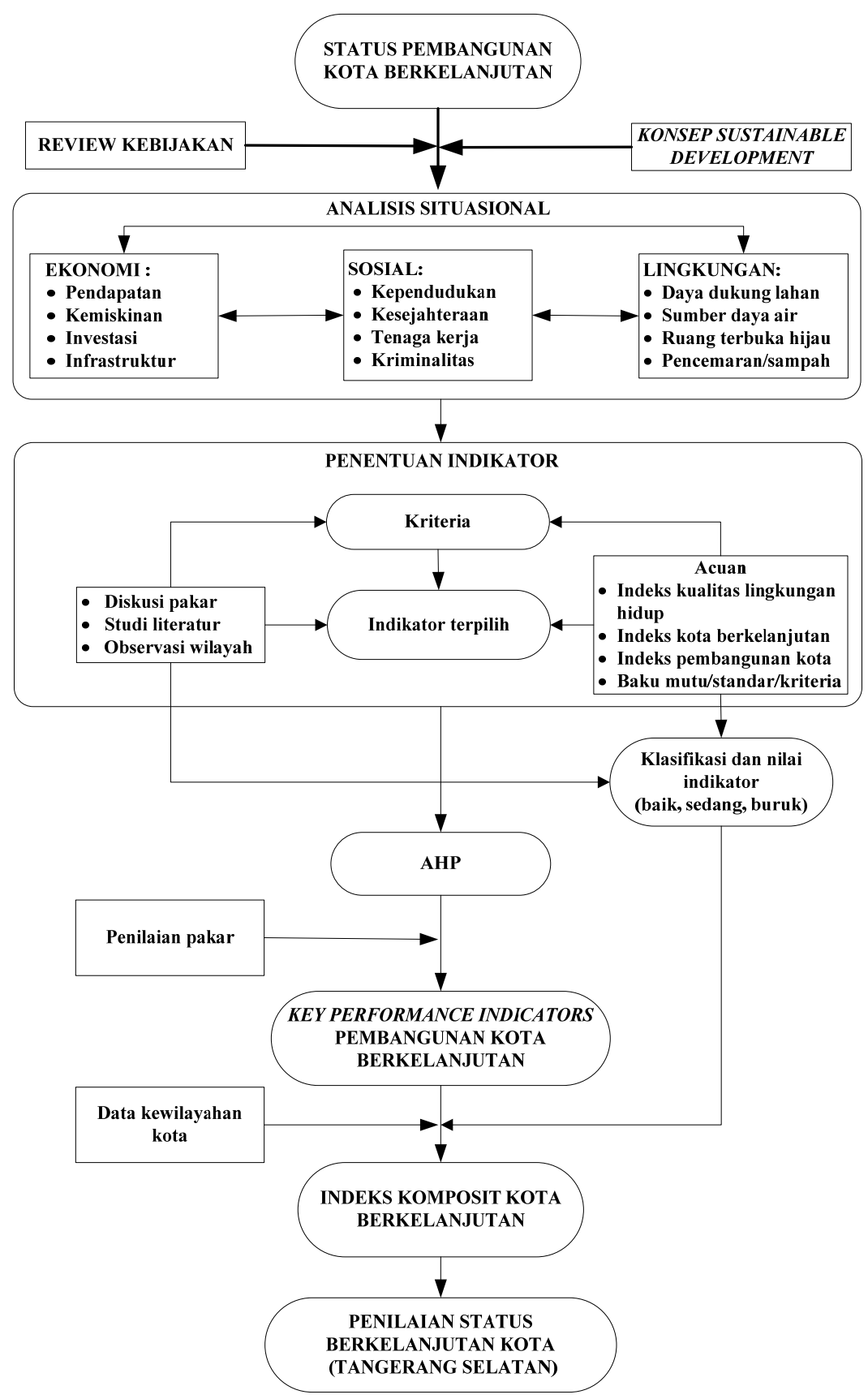

Gambar 1. Kerangka kerja penyusunan KPI.

\section{Pemilihan indikator}

Tahapan pertama ini diawali dengan pengumpulan dan review indikator atau indeks yang sudah ada. Saat ini cukup banyak indikator pembangunan berkelanjutan yang disusun berdasarkan sudut kepentingan masing-masing terutama yang terkait dengan kualitas lingkungan hidup dan pembangunan perkotaan. Beberapa referensi yang digunakan untuk direview dan dipilih indikatornya meliputi: City Development Index (CDI) yang disusun oleh United NationHabitat (Anonim, 2001); Indikator Pembangunan Berkelanjutan Kota Semarang (Semarang's
Sustainable Development Indicators -SSDIs) yang disusun oleh Setiadi, dkk. (2008); Indicators of Urban Sustainable Development disusun oleh Li, dkk. (2009); Indeks Kualitas Lingkungan Hidup (IKLH) yang disusun oleh Kementerian Lingkungan Hidup (Anonim, 2012); Indicator for Sustainable Development of Small City yang disusun oleh Visvaldisa dkk. (2013); Indikator Pembangunan Berkelanjutan Indonesia 2013 yang disusun oleh Badan Pusat Statistik (Anonim, 2013); dan Indicators for System Sustainable Assessment in Yangzhou Ecocity Development yang disusun 
oleh The China Sustainable Development Database (Anonim, 2012).

Tahapan kedua adalah penentuan kriteria. Berdasarkan beberapa referensi kemudian diidentifikasi beberapa prinsip-prinsip penting dalam penentuan indikator yang relevan, yaitu: spesifik sehingga dapat secara jelas untuk mengidentifikasi hasil; terukur sehingga sifatnya menjadi kuantitatif; praktis sehingga dapat mudah digunakan; dinamis sehingga mampu menggambarkan perubahan dari waktu ke waktu; tersedia sehingga pengumpulan data yang diperlukan untuk indikator dapat dilakukan; transparan dalam metodologi dan seleksi dengan didasarkan pada standar ilmiah; dan indikator harus mencakup aspek-aspek sosial, ekonomi, dan lingkungan suatu kota yang sesuai dengan aspek pembangunan kota baru berkelanjutan. Indikator tersebut harus dapat menunjukkan fakta, berorientasi jangka panjang, dan independen.

Tahapan ketiga selanjutnya adalah memodifikasi indikator yang akan dipergunakan. Penyusunan indikator-indikator didasarkan pada kriteria-kriteria yang sudah ada, kondisi lapangan yang ada, dan masukan dari para pakar. Indikatorindikator diambil dan diolah dari referensi-referensi indikator yang sudah ada. Seperti diketahui bahwa jumlah indikator harus dibatasi, di mana yang terpilih hanya indikator-indikator yang benar-benar terkait dengan penilaian kinerja pembangunan kota yang berkelanjutan yang terdiri dari aspek ekonomi, sosial, dan lingkungan.

\section{Pembobotan indikator dengan pendekatan AHP}

Tahapan pembobotan ini terbagi dalam 4 (empat) proses dalam memecahkan persoalan dengan analisis logis eksplisit. Proses pertama adalah melakukan penyusunan hirarki, di mana susunan hirarkis AHP terdiri dari tujuan, pilar, elemen, dan indikator untuk penilaian pembangunan kota baru berkelanjutan. Diagram pada Gambar 2 mempresentasikan keputusan untuk pembobotan pilar, elemen dan indikatornya.
Proses kedua adalah penilaian setiap level hirarki dinilai melalui perbandingan berpasangan. Menurut Saaty (1983), untuk berbagai persoalan, skala 1 sampai 9 adalah skala terbaik dalam mengekspresikan pendapat. Skala dengan sembilan satuan dapat menggambarkan derajat sampai mana kita mampu membedakan intensitas tata hubungan antar elemen. Nilai dan definisi pendapat kualitatif dari skala perbandingan Saaty dapat dilihat pada Tabel 1.

Proses ketiga adalah penentuan prioritas di mana untuk setiap level hirarki dilakukan perbandingan berpasangan untuk menentukan prioritas. Langkahnya dengan memberi bobot setiap vektor dengan prioritas sifatnya. Proses perbandingan berpasangan dimulai pada elemen yang digunakan untuk melakukan pembandingan pertama. Kemudian turun ke level indikator. Nilai nilai perbandingan relatif kemudian diolah untuk menentukan peringkat relatif dari seluruh elemen.

Proses keempat adalah mengukur konsistensi logis. AHP mengukur konsistensi menyeluruh dari berbagai pertimbangan melalui suatu rasio konsistensi. Nilai rasio konsistensi (CR) harus $\leq$ 0,1 . Jika lebih dari nilai yang sudah ditentukan maka pembobotan oleh pakar perlu ditinjau kembali.

Tabel 1. Skala perbandingan.

\begin{tabular}{ll}
\hline \multicolumn{1}{c}{ Nilai } & \multicolumn{1}{c}{ Keterangan } \\
\hline 1 & $\begin{array}{l}\text { Faktor vertikal sama penting dengan faktor } \\
\text { horizontal }\end{array}$ \\
3 & $\begin{array}{l}\text { Faktor vertikal lebih penting dari faktor } \\
\text { horisontal }\end{array}$ \\
5 & $\begin{array}{l}\text { Faktor vertikal jelas lebih penting faktor } \\
\text { horisontal }\end{array}$ \\
7 & $\begin{array}{l}\text { Faktor vertikal sangat jelas lebih penting } \\
\text { dari faktor horisontal }\end{array}$ \\
9 & $\begin{array}{l}\text { Faktor vertikal mutlak lebih penting dari } \\
\text { faktor horisontal }\end{array}$ \\
$2,4,6,8$ & $\begin{array}{l}\text { Apabila ragu-ragu antara dua nilai elemen } \\
\text { yang berdekatan }\end{array}$ \\
$1 /(2-9)$ & Kebalikan dari keterangan nilai 2-9 \\
\hline
\end{tabular}

Sumber: Saaty (1983)

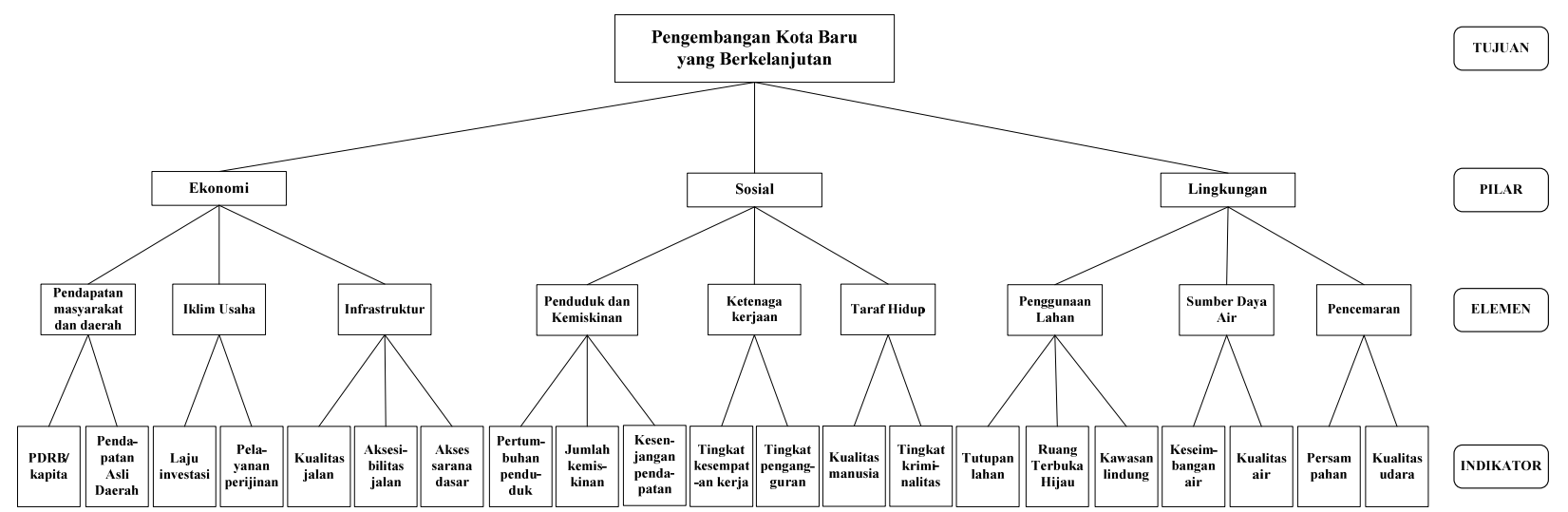

Gambar 2. Struktur hirarki AHP untuk pembobotan elemen dan indikator. 


\section{Tahapan penentuan status berkelanjutan}

Status perkembangan suatu kota baru dapat dikatakan berkelanjutan atau belum, maka diperlukan suatu klasifikasi indikator dan elemen terpilih yang didasarkan pada hasil pembobotan dengan nilai dari suatu kondisi indiktor yang ada. Untuk itu perlu terlebih dahulu dilakukan pemberian nilai pada klasifikasi kondisi masingmasing indikatornya. Penilaian tersebut adalah: nilai 1 jika indikator yang ada masuk dalam klasifikasi buruk; nilai 2 jika indikator yang ada masuk dalam klasifikasi sedang; dan nilai 3 jika indikator yang ada masuk dalam klasifikasi baik.

Penyusunan indeks berkelanjutan disusun berdasarkan nilai total tertinggi (baik) dan nilai terendah (jelek) yang mungkin tercapai dari perkalian antara hasil skoring (data kondisi kota) dan pembobotan. Nilai tertinggi yang mungkin tercapai adalah 3 , sedangkan nilai terendah adalah 1. Selanjutnya dengan mempergunakan kelas interval yang dihitung berdasarkan rentang dari nilai tertinggi dan terendah, maka status apakah

Tabel 2. Indeks komposit pengembangan kota baru berkelanjutan.

\begin{tabular}{|c|c|}
\hline Indeks berkelanjutan & Kriteria \\
\hline Berkelanjutan & Nilai total $2,35-3,00$ \\
\hline & $\begin{array}{l}\text { Salah satu nilai pilar tidak } \\
\text { boleh kurang dari } 0,75\end{array}$ \\
\hline $\begin{array}{ll}\text { Tahap } & \text { awal } \\
\text { berkelanjutan }\end{array}$ & Nilai total $1,67-2,34$ \\
\hline Belum berkelanjutan & Nilai total $1,00-1,66$ \\
\hline
\end{tabular}

suatu kota sudah berkelanjutan disajikan pada Tabel 2. Nilai akhir dari perhitungan ini merupakan indeks komposit dari 3 (tiga) pilar pembangunan berkelanjutan (ekonomi, sosial, dan lingkungan). Pendekatan ini bersifat komprehensif dan terintegrasi karena sudah mengagregatkan nilai kondisi semua indikator dan elemen kota dalam kaitannya dengan konsep pembangunan berkelanjutan.

\section{HASIL DAN PEMBAHASAN}

Kota Tangerang Selatan berada di bagian sebelah timur Provinsi Banten, dan berbatasan langsung dengan Ibukota Negara RI, yaitu Jakarta. Kota ini berfungsi sebagai daerah penyangga Kota Jakarta, dan masuk ke dalam konsep megapolitan Jabodetabekpunjur (Jakarta, Bogor, Depok, Tangerang, Bekasi, Puncak, dan Cianjur). Secara administratif terdiri dari 7 (tujuh) kecamatan, 49 (empat puluh sembilan) kelurahan dan 5 (lima) desa dengan luas wilayah $147,19 \mathrm{~km}^{2}$. Secara astronomis wilayah ini terletak pada $106^{\circ} 38^{\prime}-106^{\circ} 47^{\prime}$ BT dan $06^{\circ} 13^{\prime} 30^{\prime \prime}-06^{\circ} 22^{\prime} 30^{\prime \prime}$ LS dengan batas wilayah secara administrasi yaitu: sebelah utara berbatasan dengan Kota Tangerang, sebelah timur dengan Provinsi DKI Jakarta, sebelah selatan dengan Kabupaten Bogor dan Kota Depok (Provinsi Jawa Barat), dan sebelah barat dibatasi dengan Sungai Cisadane, Kabupaten Tangerang. Peta wilayah administrasi Kota Tangerang Selatan disajikan pada Gambar 3.

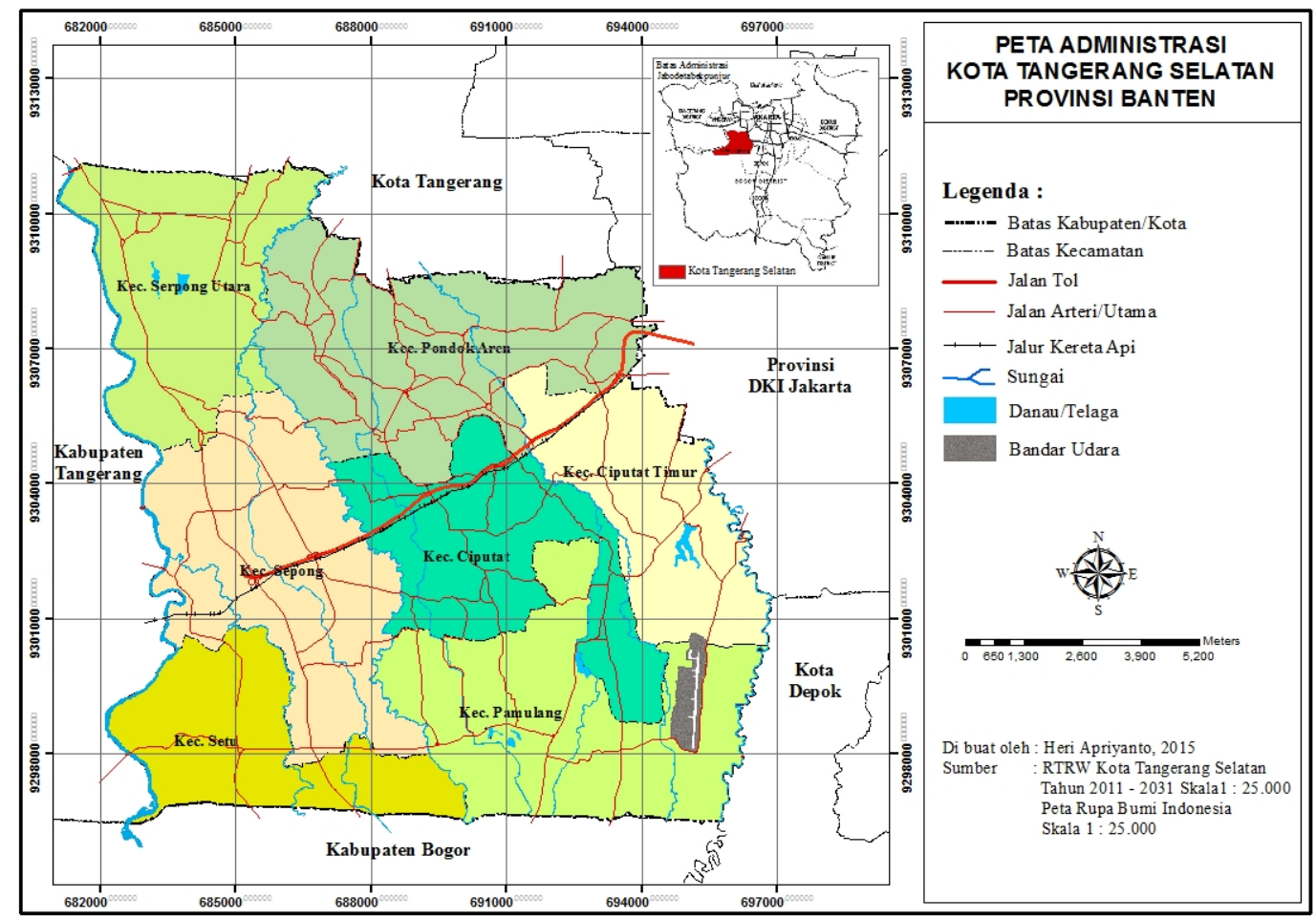

Gambar 3 Wilayah administrasi Kota Tangerang Selatan. 
Wilayah kota ini merupakan dataran rendah dengan topografi relatif datar, yaitu kemiringan lereng rata-rata $0-3 \%$ hingga kurang dari $8 \%$. Intensitas curah hujan tahunan di wilayah ini berdasarkan data tahun 1998-2012 dari Stasiun Klimatologi Pondok Betung Tangerang cukup bervariasi, yakni berkisar antara $1.080-2.910$ $\mathrm{mm} /$ tahun dengan rata-rata $2.240 \mathrm{~mm} /$ tahun. Temperatur rata-rata di wilayah ini adalah $27,6^{\circ} \mathrm{C}$.

Penggunaan lahan di wilayah kota ini didominasi oleh penggunaan lahan untuk perumahan dan permukiman, yaitu sudah mendekati $70 \%$ dari luas wilayah seluruhnya atau hampir sekitar $100 \mathrm{~km}^{2}$. Dominasi penggunaan lahan ini karena dipengaruhi adanya beberapa pusat pertumbuhan dari fungsi permukiman dan perdagangan, yaitu Kecamatan Ciputat, Pamulang, dan Pondok Aren dengan perumahan Bintaro dan Kecamatan Serpong dan Serpong Utara dengan perumahan BSD dan Alam Sutera. Pembangunan perumahan di wilayah kota ini sudah terdapat 128 kawasan perumahan.

Penduduk Kota Tangerang Selatan pada tahun 2012 berjumlah 1.355.926 jiwa dengan rata-rata tingkat kepadatan penduduknya adalah sebesar $9.544 \mathrm{jiwa} / \mathrm{km}^{2}$. Laju pertumbuhan penduduknya per tahun selama sepuluh tahun terakhir yakni dari tahun 2000 sampai dengan 2010 sebesar 4,74\%. Secara umum tingkat pendidikan yang telah ditamatkan bagi penduduk usia 10 tahun ke atas cukup memadai. Penduduk yang sudah menamatkan SMA, sebanyak 33\%, sedangkan lulusan perguruan tinggi mencapai $20 \%$. Penduduk kota ini sebagian besar bekerja di sektor perdagangan dan jasa, yakni sebesar 39\%, kemudian yang bekerja sebagai PNS sebesar 19\%. Tingkat pengangguran terbuka (TPT) cukup berfluktuasi, di mana pada tahun 2010 hanya sekitar 8,22\%, namun pada tahun 2011 melonjak sekitar $3,76 \%$ menjadi $11,98 \%$. TPT pada tahun 2012 kembali mengalami penurunan yang dratis menjadi sekitar 8,07\% (Anonim, 2013).

Kondisi perekonomian kota salah satunya dicerminkan dengan PDRB (atas dasar harga berlaku) perkapita sekitar Rp9.849.328.000.000. Laju pertumbuhan ekonominya sebesar 8,5\% (Anonim, 2013). Perkembangan PDRB kota ini cenderung menunjukkan peningkatan dari tahun ke tahun, demikian juga dengan PDRB/kapita. Sektor tersier menjadi sektor basis dan unggulan kota ini. Perkembangan sektor primer terutama sektor pertanian semakin melambat, seiring dengan berkurangnya lahan sawah akibat terjadinya alih fungsi menjadi lahan terbangun.

Penilaian status keberlanjutan pembangunan suatu kota baru diperlukan KPI yang terdiri dari indikator-indikator ekonomi, sosial, dan lingkungan. Berdasarkan hasil pemilihan indikator dengan mengacu kriteria-kriteria yang ada, pembahasan dengan para pakar, dan hasil studi referensi maka dapat ditentukan indikator-indikator sebagai KPI pembangunan kota baru berkelanjutan. Tabel 3 menunjukkan indikator-indikator yang terpilih beserta klasifikasinya.

Berdasarkan matrik perbandingan yang dibuat oleh para pakar melalui dengan metoda AHP terhadap 9 elemen dan 21 indikator maka dapat dapat diperoleh bobot dari masing-masing elemen dan indikator tersebut. Secara lengkap hasil pembobotan dapat dilihat pada Tabel 4. Perbandingan-perbandingan yang dilakukan oleh pakar yang selanjutnya diolah dengan menggunakan perangkat lunak komputer Expert Choice 2000 menunjukkan konsisten, di mana nilai rasio konsistensi (CR) nya seluruhnya di bawah 0,1 .

Hasil pembobotan para pakar terhadap elemen dan indikator yang digunakan dalam KPI pembangunan kota baru berkelanjutan maka dapat diketahui bahwa elemen untuk pilar ekonomi paling berpengaruh adalah pendapatan masyarakat dan daerah, untuk pilar sosial adalah penduduk dan kemiskinan, dan untuk pilar lingkungan adalah kondisi sumber daya air yang ada. Indikatorindikator yang mempunyai pengaruh signifikan adalah PDRB/kapita atau pendapatan masyarakat, kemudian tingkat kesenjangan pendapatan (gini ratio), dan keseimbangan air serta kualitas air.

Pengukuran status pembangunan keberlanjutan untuk Kota Tangerang Selatan dengan menggunakan KPI dengan menggunakan data kota tahun 2012 yang bersumber dari BPS, laporan dinas terkait, dan dokumen yang lainnya menunjukkan nilai akhir indeks komposit sebesar 1,949 yang berarti kota ini termasuk dalam tahap pembangunan kota yang mulai berkelanjutan. Nilai dari masingmasing pilar secara umum menunjukkan taraf yang sama, yang berarti ke tiga pilar tersebut mempunyai tingkat pengaruh yang sama dalam pembangunan kota ini.

Indikator pendapatan masyarakat yang dicerminkan dari nilai PDRB/kapita masih rendah jika dibandingkan dengan kota-kota baru hasil pemekaran tahun 1999-2014, yaitu sekitar Rp21.000.000,-. Pendapatan asli daerah Kota Tangerang Selatan mempunyai kontribusi sekitar $33,9 \%$ terhadap pendapatan daerah secara keseluruhan. Nilai ini menunjukkan bahwa kota ini mulai tahapan awal untuk mandiri dalam keuangan dan pembangunan daerah di mana ketergantungan terhadap pusat mulai berkurang.

Laju investasi yang terjadi di Kota Tangerang Selatan cukup menjanjikan. Untuk itu pemerintah 


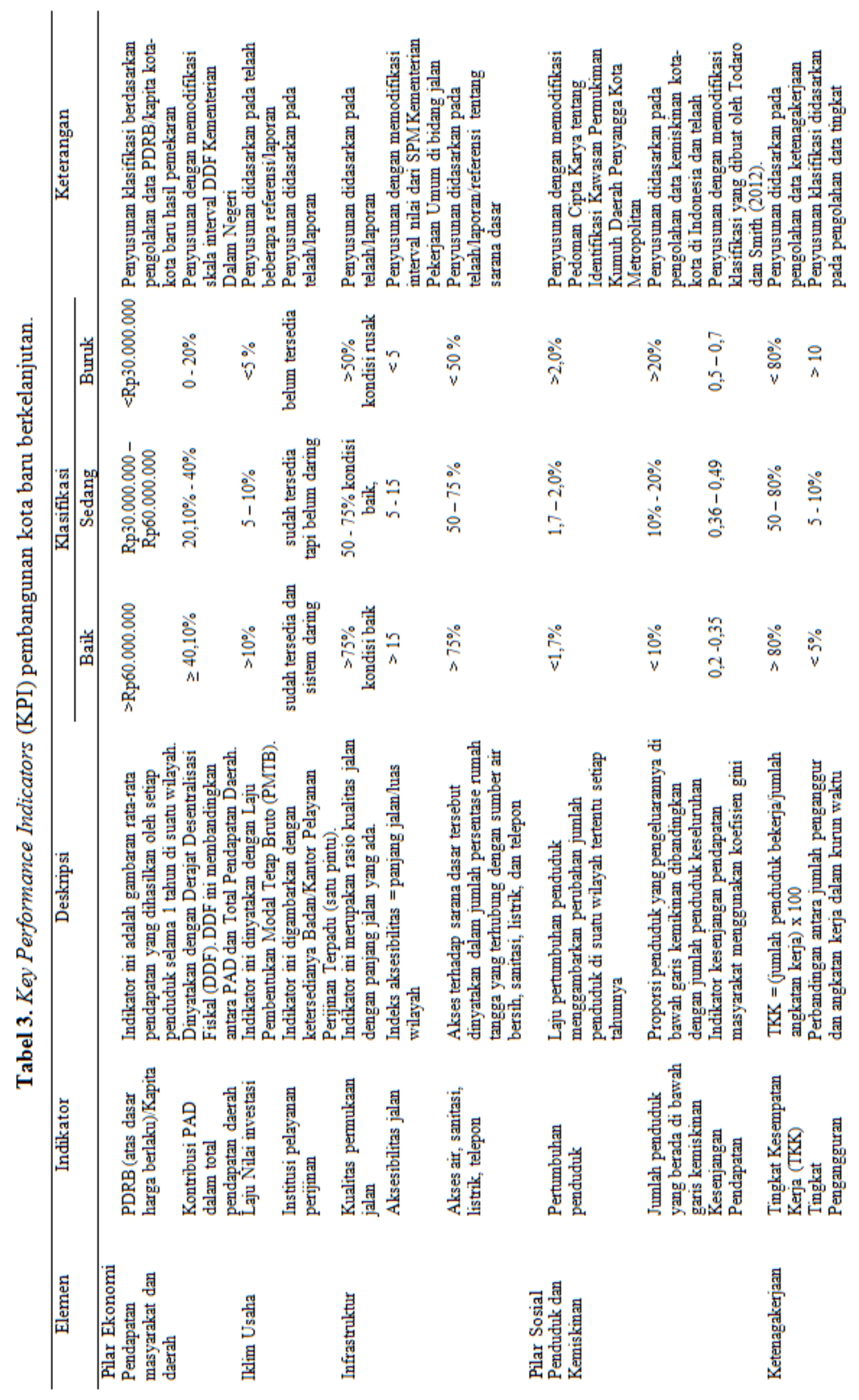




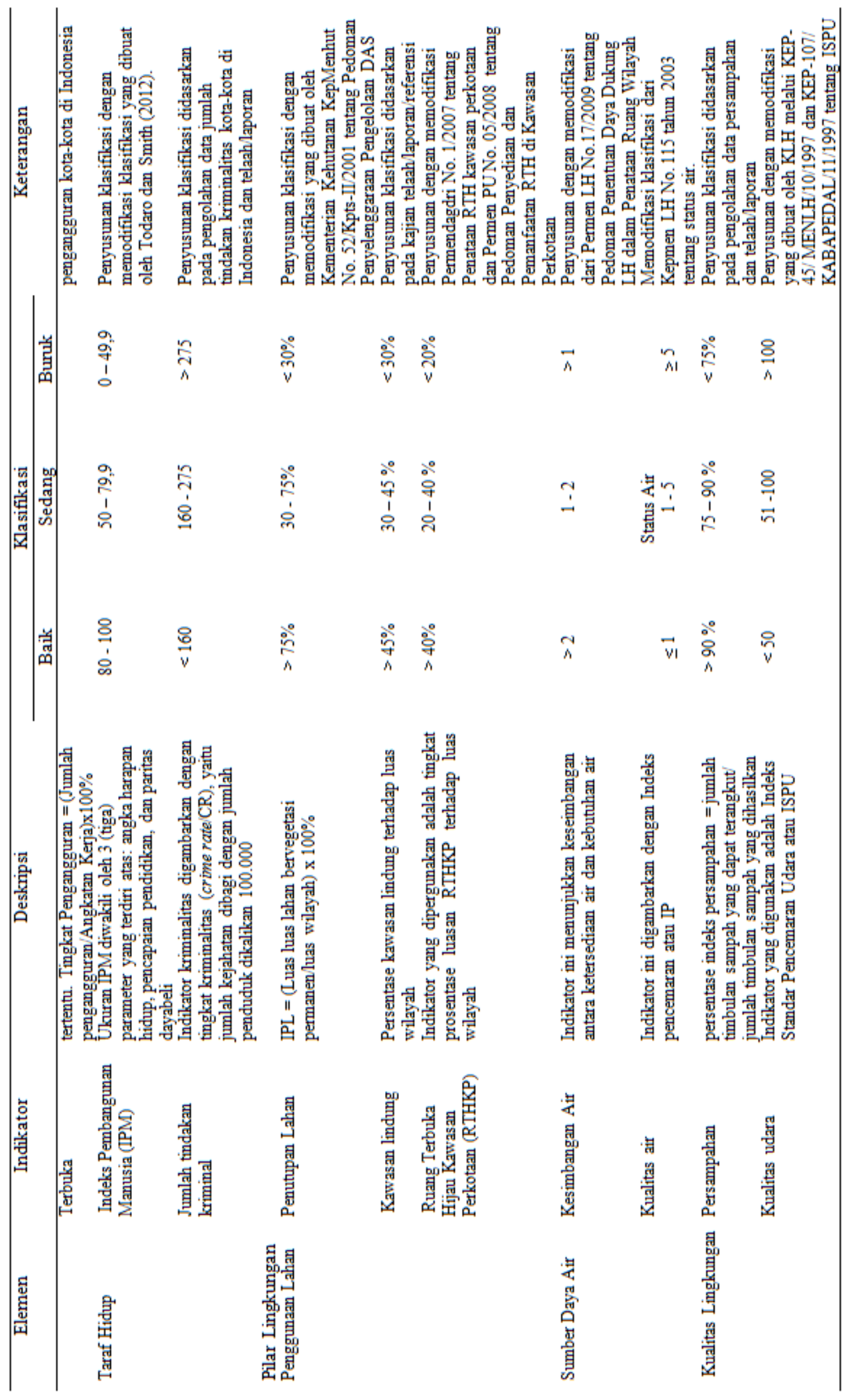




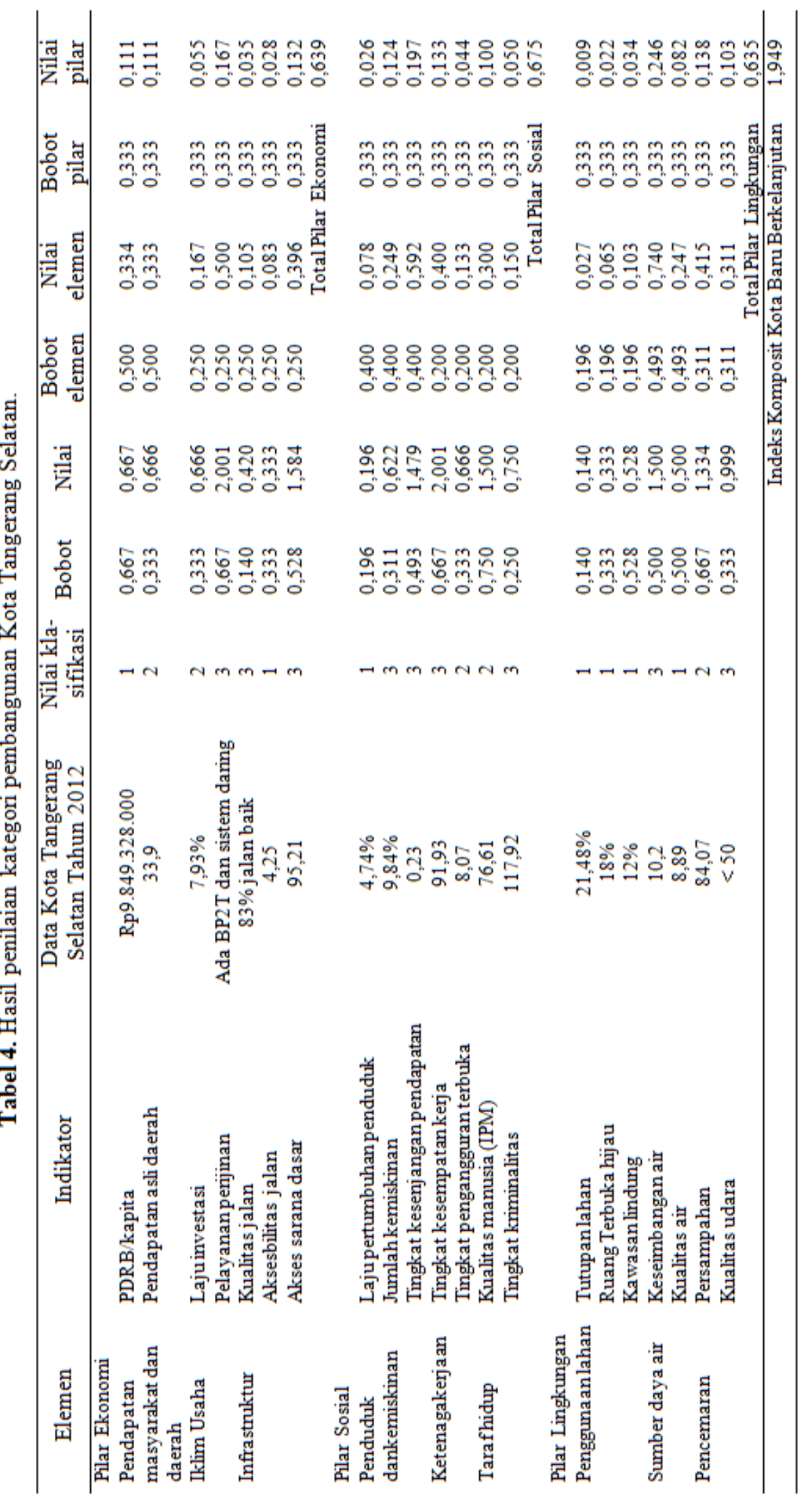


kota sudah menyiapkan sarana dan prasarana untuk menciptakan iklim usaha yang baik, antara lain dengan membentuk Badan Pelayanan Perijinan Terpadu, di mana institusi ini sudah menerapkan sistem daring. Bahkan pemerintah kota ini juga sudah membentuk suatu Badan Usaha Milik Daerah (BUMD) untuk mengelola dan mengembangkan investasi, yaitu PT Pembangunan Investasi Tangerang Selatan (PITS).

Elemen penduduk dan kemiskinan di Kota Tangerang Selatan dapat digambarkan bahwa pada dasarnya tingkat kemiskinan penduduknya dan kesenjangan pendapatan relatif cukup rendah. Namun yang menjadi masalah ke depan adalah laju pertumbuhan penduduknya yang masih tinggi, yakni di atas 4. Nilai ini jauh di atas rata-rata laju pertumbuhan penduduk secara nasional, yang berkisar sedikit di atas 2. Pertambahan penduduk ini tidak sekedar pertambahan kelahiran anak, namun juga semakin banyak migrasi masuk ke kota ini. Tingkat kesenjangan pendapatan penduduknya masih rendah yang dicerminkan dengan nilai koefisien gini sebesar 0,23. Nilai ini menggambarkan bahwa ketimpangan pendapatan yang terjadi di kota ini relatif masih dalam taraf rendah di mana pendapatan masyarakat menengah ke atas dengan masyarakat menengah ke bawah tidak jauh berbeda. Data BPS Kota Tangerang Selatan (Anonim, 2013) menunjukkan bahwa 40\% penduduk yang berpenghasilan rendah dapat menikmati $24,76 \%$ dari total pendapatan penduduk Kota Tangerang Selatan, sedangkan sisanya $50,16 \%$ dinikmati oleh 40 persen penduduk berpenghasilan menengah, dan 25,08\% dinikmati oleh $20 \%$ penduduk penghasilan tinggi. Hal ini menjadi cerminan sudah adanya pemerataan pendapatan di kota ini.

Perkembangan ekonomi dan sosial di Kota Tangerang relatif cukup baik, namun tidak demikian dengan pilar lingkungan. Hal ini tergambarkan dari element penggunaan lahan, di mana semua indikator yang termasuk ke dalam klasifikasi buruk (nilai 1). Indikator tutupan lahan menunjukkan bahwa sebagian besar wilayah ini didominasi oleh lahan terbangun. Lahan-lahan yang mempunyai vegetasi permanen semakin sempit. RTH yang ada masih di bawah batas minimal dari aturan luas RTH di suatu kota (minimal 30\% dari luas wilayah kota). RTH yang ada baru berkisar $18 \%$. RTH publik sulit untuk dikembangkan karena sebagian besar wilayah di kota ini, sekitar $80 \%$ merupakan milik pengembang/swasta.

Elemen sumber daya air dari tinjauan keseimbangan air cukup memadai. Cadangan air tanah, baik air tanah dangkal maupun dalam di wilayah ini cukup besar. Namun demikian sumber daya air tanah ini harus dijaga dan dikendalikan pemanfaatannya. Air permukaan dalam hal ini air Sungai Cisadane berdasarkan data pemantauan rutin dari Kementerian Lingkungan Hidup diketahui kualitas airnya sudah tercemar bahkan tidak dapat digolongkan untuk klasifikasi peruntukan air baku minum. Namun kenyataannya Sungai Cisadane ini masih digunakan sebagai salah satu sumber air baku untuk PDAM dalam rangka melayani kebutuhan air untuk semua sektor di Kota Tangerang Selatan.

Hal lain yang menunjukkan bahwa pembangunan kota ini belum berkelanjutan adalah permasalahan persampahan, di mana timbulan sampah yang semakin meningkat yang dihasilkan dari berbagai kegiatan penduduk maupun kegiatan perekonomian kota masih banyak yang belum dapat terangkut ke TPS maupun ke TPA. TPA yang ada belum optimal untuk pengelolaannya, sehingga masih mengandalkan pihak wilayah lain dalam mengelola sampah kota ini.

\section{KESIMPULAN}

KPI yang dihasilkan ini pada dasarnya berupaya untuk memenuhi berbagai kriteria-kriteria yang sudah ditentukan untuk dapat digunakan secara komprehensif untuk menilai status keberlanjutan pembangunan kota baru berkelanjutan. Jumlah indikator tidak perlu terlalu banyak sehingga perlu dibatasi, di mana yang terpilih adalah indikator-indikator yang benar-benar terkait dengan penilaian kinerja pembangunan kota baru berkelanjutan yang terdiri dari aspek ekonomi, sosial, dan lingkungan.

Hasil implementasi KPI untuk mengukur status keberlanjutan pembangunan Kota Tangerang Selatan menunjukkan bahwa kota ini masih belum berlanjutan secara penuh, namun masih dalam tahapan memulai. Kontribusi masing-masing pilar (ekonomi, sosial dan lingkungan) yang ada mulai menunjukkan adanya keseimbangan. Berdasarkan analisis lebih rinci maka diketahui bahwa pilar lingkungan dalam kondisi rentan. Jika tidak dilakukan suatu skenario perlindungan terhadap pilar ini, khususnya pada sumber daya air dan lahan bukan tidak mungkin pembangunan kota ini dapat menjadi tidak berkelanjutan karena adanya faktor keterbatasan. Lahan semakin banyak yang terbangun, sedangkan luasan lahan bervegetasi jauh dari standar yang ada. Sampah yang dihasilkan masyarakat dan kegiatan perekonomian semakin meningkat tetapi pengelolaannya belum dilakukan secara optimal. 


\section{UCAPAN TERIMAKASIH}

Kami menyampaikan ucapan terima kasih kepada Kementerian Riset, Teknologi dan Pendidikan Tinggi; Badan Pengkajian dan Penerapan Teknologi; dan Institut Pertanian Bogor yang telah memberikan kemudahan dan dukungan terhadap pelaksanaan penelitian ini.

\section{DAFTAR PUSTAKA}

Anonim, 2001. Global Urban Indicator Database Version 2. UN-HABITAT Publications, Nairobi.

Anonim, 2012. Indeks Kualitas Lingkungan Hidup 2011. Kementerian Lingkungan Hidup, Jakarta.

Anonim, 2012. Indicators for Sustainability: How Cities are Monitoring and Evaluating Their Success. The China Sustainable Development (CSD) Database. CSD, China.

Anonim, 2013. Kota Tangerang Selatan dalam Angka 2012. Badan Pusat Statistik, Tangerang Selatan.

Anonim, 2013. Indikator Pembangunan Berkelanjutan 2013. Badan Pusat Statistik, Jakarta.

Chen, M.C., Ho, T.P., dan Jan, C.G., 2006. A System Dynamics Model of Sustainable Urban Development: Assessing Air Purification Policies at Taipei City. Asian Pacific Planning Review, 4(1):29-52.

Diaz, R. A., 2011. Planning for Sustainable Development: Strategic Alignment in Peruvian Regions and Cities. Futures, 43: 908-918.

Dou, X., Li, S., dan Wang, J., 2013. Ecological Strategy of City Sustainable Development. APCBEE Procedia, 5:429 - 434.
Guan, D., Gao,W., Su, W., Li, H., dan Hokao, K., 2011. Modeling and Dynamic Assessment of Urban Economy-Resource-Environment System with a Coupled System Dynamics Geographic Information System Model . Ecological Indicators, 11:1333-1344.

Li, F., Liu, X., Hu, D., Wang, R., Yang, W., Li, D., dan Zhao, D., 2009. Measurement Indicators and an Evaluation Approach for Assessing Urban Sustainable Development: A Case Study for China's Jining City. Landscape and Urban Planning, 90:134-142.

Mori, K. dan Christodoulou, A., 2012. Review of Sustainability Indices And Indicators: Towards a New City Sustainability Index (CSI). Environmental Impact Assessment Review, 32:94-106

Setiadi, R., Jawoto, S., Sophianingrum, M., dan Rosalia, D., 2008. Indikator Pembangunan Berkelanjutan Kota Semarang. Riptek, 1(2):115.

Saaty, T.L., 1983. Decision Making For Leaders: The Analytical Hierarchy Process for Decision in Complex World. RWS Publication, Pittsburgh.

Setyowati, D.L., 2008. Iklim Mikro dan Kebutuhan Ruang Terbuka Hijau di Kota Semarang. Jurnal Manusia dan Lingkungan, 15(3):125140.

Todaro, M.P. dan Smith, S.C., 2012. Economic Development. 11th edition. Pearson Education Inc, Boston.

Visvaldisa, V., Ainhoab, G., dan Ralfsc, P., 2013. Selecting Indicators for Sustainable Development of Small Towns: The Case of Valmiera Municipality. Procedia Computer Science, 26:21 - 32. 